\title{
Section 5(a) of the Clayton Act and Offensive Collateral Estoppel in Antitrust Damage Actions
}

The common law of collateral estoppe ${ }^{1}$ has developed in a direction which brings it into potential conflict with the statutory provisions governing the effect of antitrust judgments in subsequent antitrust suits. Section 5(a) of the Clayton Act provides that a judgment against a defendant in a government antitrust enforcement suit shall be prima facie evidence against that defendant in a subsequent suit by another party. ${ }^{2}$ The presumption extends to all issues of fact and law which were necessarily decided against the defendant in order to reach the judgment. $^{3}$

1. The doctrine of collateral estoppel may be stated as follows:

When an issue of fact or law is actually litigated and determined by a valid and final judgment, and the determination is essential to the judgment, the determination is conclusive in a subsequent action between the parties, whether on the same or a different claim.

Restatement (SECOND) of Judgments $\$ 68$ (Tent. Draft No. 1, 1973). The rationale for the doctrine is that once a party has had a full and fair opportunity to litigate an issue in court, he should not be allowed to relitigate that issue in a subsequent proceeding. Bruszewski v. United States, 181 F.2d 419, 421 (3d Cir.), cert. denied, 340 U.S. 865 (1950).

2. Section 5(a) provides:

A final judgment or decree heretofore or hereafter rendered in any civil or criminal proceeding brought by or on behalf of the United States under the antitrust laws to the effect that a defendant has violated said laws shall be prima facie evidence against such defendant in any action or proceeding brought by any other party against such defendant under said laws or by the United States under section 15a of this title, as to all matters respecting which said judgment or decree would be an estoppel as between the parties thereto: Provided, That this section shall not apply to consent judgments or decrees entered before any testimony has been taken or to judgments or decrees entered in actions under section 15a of this title.

15 U.S.C. \$ 16(a) (1970). The Clayton Act provides for three principal types of antitrust actions. A "government enforcement action" is a criminal or equitable action brought by the Attorney General of the United States to enforce the antitrust laws under 15 U.S.C. $\$ \$ 4,9,25$ (1970). (For the purposes of this Note, the term "government enforcement action" also refers to a Federal Trade Commission proceeding brought to enforce the antitrust laws under 15 U.S.C. $\$ 21$ (1970). See note 54 infra.) Such a suit should be brought only when the Justice Department deems it to be in the public interest. See pp. 555-56 infra. A "private treble damage action" is a suit by a private party brought under $\S 4$ of the Clayton Act, 15 U.S.C. $\$ 15$ (1970), to recover damages for injuries suffered as the result of a defendant's violation of the antitrust laws. (A private plaintiff may also obtain injunctive relief against an antitrust violator under 15 U.S.C. $\$ 26$ (1970). For the purposes of this Note, all private antitrust actions will be referred to as "damage" actions.) A "government damage action" is a suit by the United States brought under $\$ 4 A$ of the Clayton Act, 15 U.S.C. $\$ 15$ a (1970), to recover actual damages for injuries suffered in its business or property from violations of the antitrust laws. See note 28 infra.

3. Emich Motors Corp. v. Gencral Motors Corp., 340 U.S. 558, 569 (1951). 
When Congress enacted $\S 5(\mathrm{a})$ in 1914 , a judgment in a prior antitrust suit could not be used to estop the defendant in a subsequent action unless the party asserting collateral estoppel would have been bound by the prior judgment. ${ }^{4}$ This result followed from the judgemade doctrine of mutuality of estoppel:

[u]nless both parties (or their privies) in a second action are bound by a judgment in a previous case, neither party (nor his privy) in the second action may use the prior judgment as determinative of an issue in the second action. ${ }^{5}$

As a matter of due process of law, a nonparty may not be bound by a judgment in a prior action unless he is represented by, or in privity with, a party to that action. ${ }^{6}$ Under the mutuality rule, then, a party to an action will be estopped by a prior judgment only when both he and his opponent were parties (or in privity with parties) to the prior action.

Over the past 30 years courts have gradually abandoned the mutuality rule. ${ }^{7}$ In the leading case of Blonder-Tongue Laboratories, Inc. $v$. University of Illinois Foundation, the Supreme Court noted the trend away from the mutuality requirement in state and federal courts and held unanimously that a defendant in a patent infringement suit could estop a patentee from relitigating a patent declared invalid in a prior

4. Buckeye Powder Co. v. E.I. duPont de Nemours Powder Co., 248 U.S. 55, 63 (1918); Bigelow v. Old Dominion Copper Mining and Smelting Co., 225 U.S. 111, 127 (1912); Note, Using Government-Obtained Judgments to Prove the Conspiratorial Nalure of Subsequent Refusals to Deal: The Joker in Private Antitrust Litigation, 69 YALE. L.J. 462, 463-64 (1960).

5. Blonder-Tongue Laboratories, Inc. v. University of Ill. Foundation, 402 U.S. 313, 320-21 (1971). For discussions of the mutuality principle, see RESTATEMENT (SECOND) OF Judgments $\$ 88$ (Tent. Draft No. 2, 1975); 1B Mloore's Federal Practice f $0.412[1]$ at 1801-34 (2d ed. 1974); Currie, Civil Procedure: The Tempest Brews, 53 C.aL. L. Rev. 25 (1965); Currie, Mutuality of Collateral Estoppel: Limits of the Bernhard Doctrine, 9 STAN. L. REv. 281 (1957); Semmel, Collateral Estoppel, Mutuality and Joinder of Parties, 68 Colum. L. REv. 1457 (1968); Note, The Impacts of Defensive and Offensive Assertion of Collateral Estoppel by a Nonparty, 35 GEo. WASH. L. REv. 1010 (1967).

6. Blonder-Tongue Laboratories, Inc. v. University of Ill. Foundation, 402 U.S. 313, 329 (1971). But cf. Note, Collateral Estoppel of Nonparties, 87 HARv. L. REv. 1485 (1974) (discussion of cases in which nonparties have been bound).

7. The first major case in which a court explicitly departed from the mutuality rule was Bernhard v. Bank of America Nat'l Trust \& Sav. Ass'n, 19 Cal. 2d 807, 812, 122 P.2d 892, 895 (1942). Writing for a unanimous court, Justice Traynor discussed the mutuality doctrine in detail and concluded that "[n]o satisfactory rationalization has been advanced for the requirement." Since Bernhard, numerous state and federal courts have also rejected the mutuality requirement. See, e.g., Zdanok v. Glidden Co., 327 F.2d 944 (2d Cir. 1964); Bruszewski v. United States, 181 F.2d 419 (3d Cir.), cert. denied, 340 U.S. 865 (1950); Schwartz v. Public Adm'r, 24 N.Y.2d 65, 246 N.E.2d 725, 298 N.Y.S.2d 955 (1969); RESTAtement (SECOND) of Judgmets $\$ 88$ (Tent. Draft No. 2, 1975) (collecting cases); Note, supra note 5, at 1017-24 nn.58-107 (1967). 
infringement suit by the patentee against another defendant. ${ }^{8}$ Some courts have gone beyond the "defensive" use of collateral estoppel against a plaintiff by a defendant not a party to the prior action and allowed "offensive" use of collateral estoppel against a defendant by a plaintiff not a party to the prior action. ${ }^{9}$

Allowing offensive collateral estoppel against a defendant who has lost in a prior government enforcement suit would go beyond the prima facie presumption which $\S 5(\mathrm{a})$ creates. ${ }^{10}$ The government judgment would have conclusive rather than merely prima facie effect in a subsequent suit by another party, precluding the defendant from relitigating any issues necessarily decided against him in the prior suit. ${ }^{11}$ Allowing offensive collateral estoppel against a defendant who has lost in a prior private treble damage suit would give conclusive effect to the private judgment where no statutory presumption was

8. 402 U.S. $313,320-27,349-50$ (1971). The circumstances surrounding the BlonderTongue decision suggest that the Supreme Court saw the case as an opportunity to endorse the trend away from mutuality. Blonder-Tongue overruled Triplett v. Lowell, 297 U.S. 638 (1936), which had held that a prior judgment against a patentee would not estop him from relitigating the validity of his patent against a new defendant. In Blonder-Tongue, the Court noted that Triplett had stood in the way of lower courts who wished to depart from the mutuality rule, and it took the unusual step of overruling Triplett even though both parties advocated retention of the rule in their briefs. (The United States, appearing as amicus curiae, urged a departure from the Triplett rule.) 402 U.S. at 318-19.

9. E.g., Zdanok v. Glidden Co., 327 F.2d 944, 954-56 (2d Cir. 1964); United States v. United Airlines, 216 F. Supp. 709, 725-30 (E.D. Wash., Nev. 1962), aff'd as to res judicata sub nom. United Air Lines v. Wiener, 335 F.2d 379, 404-05 (9th Cir. 1964); B.R. DeWitt, Inc. v. Hall, 19 N.Y.2d 141, 225 N.E.2d 195, 278 N.Y.S.2d 596 (1967). See Blonder-Tonguc Laboratories, Inc. v. University of Ill. Foundation, 402 U.S. 313, 329-30 \& n.19 (1971); Note, supra note 5, at 1032-37.

10. Section $5(a)$ deals only with the offensive use of a prior judgment against a defendant in an antitrust suit by a third party. The principles advanced in Blonder-Tongue, see note 13 infra, clearly govern the defensive use of collateral estoppel against a plaintiff suing under the antitrust laws. Citing Blonder-Tongue, at least three courts recently have granted summary judgment against plaintiffs in antitrust suits, on the ground that the plaintiffs were bound by issues of law and fact decided against them in a prior action. Poster Exch., Inc. v. National Screen Serv. Corp., 517 F.2d 117, 122-23 (5th Cir. 1975); Scooper Dooper, Inc. v. Kraftco Corp., 494 F.2d 840, 844-45 (3d Cir. 1974); Raitport v. Commercial Banks, 391 F. Supp. 584 (S.D.N.Y. 1975). Three other courts have suggested in dicta that defensive collateral estoppel may be used in antitrust litigation. International Tel. \& Tel. Corp. v. General Tel. \& Elec. Corp., 380 F. Supp. 976, 983 n.7 (M.D.N.C. 1974); In re Master Key Antitrust Litigation, 1973-2 Trade Cas. If 74,680, at 94,979 \& n.8 (D. Conn. 1973); Boshes v. General Motors Corp., 59 F.R.D. 589, 596 (N.D. Ill. 1973). But cf. Carnivale Bag Co., Inc. v. Slide-Rite Mfg. Corp., 395 F. Supp. 287, 292 n.8 (S.D.N.Y. 1975) (criticizing Boshes and Master Key for failing to recognize that a litigant may not be estopped by a prior judgment to which he was not a party).

11. Collateral estoppel is an equitable doctrine and hence does not always preclude a party from relitigating issues previously decided against him. A court will estop a party if he has had a full and fair opportunity to litigate an issue, unless in the circumstances of the case the estoppel would not serve the interests of justice. See RESTATEMENT (SECOND) of Judcments $\S 68.1$ (Tent. Draft No. 1, 1973); Id. $\$ 88$ (Tent. Draft No. 2, 1975). 
created by Congress. To give conclusive effect to judgments in prior private or government antitrust actions would permit subsequent antitrust plaintiffs to obtain summary judgment on the issue of liability and to recover damages on a showing of injury from the defendant's violation.

The issue of whether offensive collateral estoppel should be allowed in private treble damage actions has arisen in recent litigation. ${ }^{12}$ The

12. Relying on the doctrine of offensive collateral estoppel, plaintiffs have moved for summary judgment in a number of recent private treble damage suits. In each case the plaintiff argued that a prior judgment finding the defendant in violation of the antitrust laws should estop the defendant from relitigating the issue of liability. McCook v. Standard Oil Co., 393 F. Supp. 256 (C.D. Cal. 1975); In re IBM Pcripheral EDP Devices Antitrust Litigation, No. 163 (Jud. Pan. Multidist. Litig., motion denied, Aug. 21, 1974); Levin v. IBM, No. 1173-72 (D.N.J., motion denied Jan. 17, 1974); In re Gypsum Cases, No. 46414-A (N.D. Cal. Dec. 22, 1971) (granting partial judgment on plaintiffs' claims of violation of Section 1 of Sherman Act); Purex Corp., Ltd. v. Procter \& Gamble Co., 308 F. Supp. 584 (C.D. Cal. 1970), aff'd, 453 F.2d 288 (9th Cir. 1971), cert. denied, 405 U.S. 1065 (1972). Summary judgment was granted in Gypsum and denied in all the other cases.

Gypsum has limited precedential value because it allowed one group of plaintiffs to assert offensive collateral estoppel in a consolidated action under the Multidistrict Litigation Act, 28 U.S.C. $\S 1407$ (1970), after another group had obtained a judgment against the defendant. The plaintiffs had been separated into two groups at the court's direction to facilitate trial. All the plaintiffs had participated in two years of pretrial proceedings, and all had cases pending before the court throughout the trial which resulted in the judgment against the defendant. In granting summary judgment to the second group of plaintiffs on the issue of liability, the court did not even mention $\$ 5(a)$ of the Clayton Act. See In re Gypsum Cases, supra, slip op. at 1.

The IBM litigation involved the same issues of monopolization in the computer in dustry that were litigated in Telex Corp. v. IBM, 367 F. Supp. 258 (N.D. Okla. 1973), rev'd in part and aff'd in part, 510 F.2d 894 (10th Cir. 1975). After Telex won a judgment against IBM at trial, eight other computer companies sought partial summary judgment against IBM on their claims. In In re IBMI Peripheral EDP Devices Antitrust Litigation, supra, the court denied the plaintiffs' motion from the bench. In Levin $v$ IBM, supra, slip op. at 4, however, the court issued a written opinion which relied on $\S 5(a)$ :

The defendant argues, and convincingly so, that Section 5 of the Clayton Act only permits former anti-trust adjudications by the government to be given weight in subsequent private actions .... Defendant further argues that even the government adjudication can only be given a prima facie evidentiary value and not the conclusive presumptive effect that the plaintiff urges for the Telex decision as collateral estoppel.

In Purex Corp. v. Procter \& Gamble Co., supra at 589-90, the court dismissed the plaintiff's motion for summary judgment with the mere observation that $\$ 5(a)$ governcd:

According to section $5(\mathrm{a})$, the [prior decree] must be admitted in this case as prima

facie evidence ....

.....

But application here on the principle of collateral estoppel, as urged by the plaintiff would mean that the [prior decree] would be conclusive as to all matters to which it applied. The [prior decree] cannot be both prima facie and conclusive; and, it having been determined that the statute applies, the statute must govern.

The most thorough discussion by a court of the relationship between $\S 5(a)$ and offensive collateral estoppel appears in McCook v. Standard Oil Co., supra. However, McCook was decided on other grounds, and the court expressly reserved the question whether $\$ 5$ (a) preempts the use of offensive collateral estoppel. 393 F. Supp. at 359.

The United States has never sought to use offensive collateral estoppel in an enforce- 
evolving common law of collateral estoppel, as established by BlonderTongue and other cases, provides principles of equity and efficiency to guide the courts in deciding the appropriate circumstances in which mutuality of estoppel should not be required. ${ }^{13}$ But in the area of

ment suit against a defendant who had lost in a prior private treble damage action. Such a case is conceivable (although private antitrust suits almost always follow, rather than precede, government enforcement actions against the same defendant. See pp. 559-60 infra). For example, before Telex Corp. v. IBM, supra, was reversed, the Justice Department amended the complaint in its enforcement suit against IBM to allege the violations found by the trial court in Telex. Compare id. with Lnited States v. IBM, 1975 Trade Cas. ff 60,104 (S.D.N.Y. 1975).

13. At least one commentator has assumed that the Court's justifications in BlonderTonguc for allowing defensive collateral estoppel in patent infringement suits would support the use of offensive collateral estoppel in antitrust actions. Note, Section 5(a) of the Clayton Act and the Use of Collateral Estoppel by a Private Plaintiff in a Treble Damage Action, 8 U.S.F. L. RFv. 74, 79 \& $n .34$ (1973). On analysis, this assumption proves incorrect.

Writing for a unanimous Court, Justice White distinguished between the use of offensive and defensive collateral estoppel, noting that

the authorities have been more willing to permit a defendant in a second suit to invoke an estoppel against a plaintiff who lost on the same claim in an earlier suit than they have been to allow a plaintiff in the second suit to use offensively a judgment obtained by a different plaintiff in a prior suit against the same defendant.

402 U.S. at $329-30$ (footnote omitted). He then advanced three reasons for allowing defensive collateral estoppel in patent infringement suits: (I) it would not frustrate the congressional policies represented by the patent statutes; (2) it would reduce economic costs imposed on alleged infringers; and (3) it would reduce the burden on the federal courts from relitigation of patents once held invalid. Id. at 330-49.

This reasoning cuts against the use of offensive collateral estoppel in antitrust actions. First, giving conclusive effect to private judgments would obstruct the congressional policy of according government suits the primary role in enforcing the antitrust laws. See pp. 555-63 infra. Second, permitting treble damage plaintiffs to assert collateral estoppel in antitrust actions would impose the very type of economic costs on defendants that the Court in Blonder-Tongue sought to avoid by permitting defendants to assert defensive collateral estoppel in patent litigation.

Justice White pointed to the economic consequences of allowing patentees to relitigate patents once declared invalid: "prospective defendants will often decide that paying royalties under a license or other settlement is preferable to the costly burden of challenging the patent." 402 U.S. at 338 . Failure to give conclusive effect to a prior determination of invalidity tended "to multiply the opportunities for holders of invalid patents to exact licensing agreements or other settlements from alleged infringers." Id. at 342. However, giving conclusive effect to prior antitrust judgments would increase the coercive pressure on defendants to settle which the Court was attempting to prevent in Blonder-Tongue. If a judgment that a defendant has violated the antitrust laws were to have conclusive effect in every future treble damage suit against the same defendant, many prospective defendants would be tempted to settle all but the most frivolous claims against them, rather than risk the enormous damage liability which would result from losing the suit. See Handler, The Shift From Substantive to Procedural Innovations in Antitrust Suits-The Twenty-Third Annual Antitrust Review, 71 Colvm. L. REv. 1, 8-9 (1971) (threat of astronomical recovery in class action treble damage suits operates as "legalized blackmail" to force antitrust defendants to settle even frivolous claims). Section 5 (a) now induces defendants to settle government enforcement suits to avoid the prima facie presumption given to judgments in such suits in subsequent private treble damage actions. See p. 561 infra. Attaching a conclusive presumption to prior judgments would make defendants even more reluctant to risk litigation. And attaching this conclusive presumption to private judgments is particularly apt to coerce defendants to settle meritless claims, because private suits, unlike government enforcement suits, are 
antitrust, Congress has enacted a statute, $\$ 5(a)$ of the Clayton Act, to provide for the effect of prior judgments in a subsequent action by another party. ${ }^{14}$ The threshold question is thus whether $\$ 5(\mathrm{a})$ leaves courts free to give conclusive effect to judgments obtained in government enforcement or private actions, or whether its prima facie presumption preempts developments in the common law of collateral estoppel. Although no reported case has thoroughly considered the question, several commentators have asserted that $\$ 5(a)$ does not preclude the use of offensive collateral estoppel in antitrust actions..$^{15}$

motivated by the plaintiff's economic self-interest. See pp. 555-57 infra.

Justice White characterized his final justification for estoppel-reduction of litigationas "an incidental matter" compared to the economic considerations on which he placed most emphasis. 402 U.S. at 349. Moreover, this last reason does not argue strongly for applying offensive collateral estoppel to government judgments, because such judgments already receive prima facie effect under $\$ 5(\mathrm{a})$, thus promoting judicial cfficiency and reducing costs to litigants. McCook v. Standard Oil Co. of Cal., 393 F. Supp. 256, 258 (C.D. Cal. 1975).

Hence, even absent the $\$ 5(a)$ provisions for the effect of antitrust judgments, on which the analysis of this Note relies, it is not at all clear that Blonder-Tongue compels the use of offensive collateral estoppel in antitrust actions. Moreover, the Court in Blonder-Tongue did not mention yet another problem with the abandonment of mutuality-the effect on a party's right to jury trial. A defendant has no right to a jury trial in a government civil enforcement action, McCook v. Standard Oil Co. of Cal., $393 \mathrm{~F}$. Supp. 256, 258 (C.D. Cal. 1975); 5 Moore's Feneral Practice, supra note 5, I 38.37[2], at 308, and estopping a defendant who has lost in a prior government enforcement suit would prevent the defendant from trying his case to a jury in a subsequent treble damage action. Courts have been reluctant to restrict a defendant's right to a jury trial through the use of collateral estoppel or res judicata. E.g., Beacon Theatres v. Westover, 359 U.S. 500 (1950) (no res judicata effect to prior declaratory judgment in private antitrust action between identical parties); Rachal v. Hill, 435 F.2d 59 (5th Cir. 1970), cert. denied, 403 U.S. 94 (1971) (no collateral estoppel effect to prior Securities Exchange Commission judgment in civil action for damages against prior defendant); McCook v. Standard Oil Co. of Cal., supra (no collateral estoppel effect to prior judgment in government antitrust enforcement action in private treble damage suit against prior defendant).

14. Section $5($ a) does not apply to the effect given a prior judgment in a subsequent suit between the same parties (except in a government damage suit following a government enforcement suit, see pp. $552-53$ infra). See Minnesota Mining \& Mfg. Co. v. New Jersey Wood Finishing Co., 381 U.S. 311,317 (1965) (dictum). In a subsequent suit between the same parties, principles of res judicata and collateral estoppel control. Sec Local 167, Teamsters v. United States, 291 U.S. 293, 298-99 (1934) (criminal prosccution for violation of the Sherman Act followed by government suit for injunctive relief); Florists Nationwide Tel. Delivery Network v. Florists' Tel. Delivery Ass'n, 371 F.2d 263, 270-7I (7th Cir.), cert. denied, 387 U.S. 909 (1966) (action for damages under Clayton Act followed by action for injunctive relief) (dictum); Perryton Wholesale, Inc. v. Pioneer Distrib. Co., 353 F.2d 618, 623 (10th Cir. 1965), cert. denied, 383 U.S. 945 (1966) (judgment in injunctive action under the Clayton Act followed by action for damages); Boise Cascade Int'l, Inc. v. Northern Minnesota Pulpwood Prods. Ass'n, 291 F. Supp. 1015, 1017 (D. Minn. 1968) (dictum); United States v. National City Lines, 118 F. Supp. 465, 467 (N.D. I1l. 1953); United States v. Greater N.Y. Live Poultry Chamber of Commerce, 53 F.2d 518 (S.D.N.Y. 1931).

15. Note, supra note 13, at 81-89; Note, Closing an Antitust Loophole: Collatcral Effect for Nolo Pleas and Government Setllements, 55 V.. L. REv. 1334, 1345-46 \& n.45 (1969). See Langsdorf, United States as Antitrust Damage Plaintiff: Mistreatcd Stcprhild of the Parens Patriae, 16 Antranust Bul.t. 187, 202-12 (1971). 
This Note contends that the answer to this question lies in large part in congressional treatment of the government damage action-a hybrid between the government enforcement action and the private treble damage action, in which the Government sues not to enforce the antitrust laws in the public interest but to recover damages for injuries suffered in its proprietary capacity from antitrust violations. ${ }^{16}$ When Congress created the government damage action in 1955, it amended $\$ 5$ in two important ways. It provided ( 1 ) that judgments in government enforcement actions should be prima facie evidence in subsequent government damage actions, as they are in subsequent private damage actions, and (2) that judgments in government damage actions, unlike those in government enforcement actions, should not be given prima facie effect in subsequent suits. These amendments to $\S 5$, in the context of the legislative history of the section since its original enactment in 1914 and the policy of Congress toward the enforcement of the antitrust laws through government and private suits, evince a congressional intent to deny conclusive effect to prior judgments obtained in either government or private antitrust suits.

\section{The Effect of Prior Government Judgments}

Section 5(a) provides specifically for the effect of a prior judgment against a defendant who has lost in a government antitrust enforcement action: the judgment "shall be prima facie evidence against such defendant in any [antitrust] action or proceeding brought by any other party." 17 While $\S 5(a)$ does not explicitly state that judgments in government enforcement actions can only be given prima facie effect, a long recognized rule of statutory construction is that the specification of one standard implies the exclusion of all others-expressio unius est exclusio alterius. ${ }^{18}$ Applying this rule of construction, a court would interpret $\S 5(\mathrm{a})$ as prohibiting the use of offensive collateral estoppel to give government judgments conclusive effect in subsequent suits by

16. See notes 2 supra, 28 infra.

17. 15 U.S.C. $\$ 16(a)(1970)$.

18. E.g., Continental Casualty Co. v. United States, 314 U.S. 527, 532-33 (1942) (statute providing that a court may remit the whole or a part of a forfeited bail bond "whenever it appears to the court that there has been no willful default" forbids a court to exercise any common law power of remittance it might have had prior to the statute); KnappMonarch Co. v. Commissioner, 139 F.2d 863, 864 (8th Cir. 1944) ("The very fact that Congress has provided a way in which the Internal Revenue Department may bind itself [in an agreement as to the extent of a taxpayer's liability], precludes the possibility of its being bound by some other procedure."); United States v. Robinson, 359 F. Supp. 52, 5859 (S.D. Fla. 1973) (statute providing for authorization of wiretaps by the "Attorney (ieneral or any Assistant Attorney General specially designated by the Attorney General" does not allow authorization by any other party). 
third parties. Indeed, during the gradual erosion of the mutuality requirement, courts have consistently relied on $\$ 5(\mathrm{a})$ in refusing to give judgments in government enforcement actions conclusive effect in subsequent private treble damage actions. ${ }^{19}$ Nonetheless, the expressio unius maxim is only an aid to construction, not a rule of law. ${ }^{20}$ It could not override clear evidence that Congress intended, if common law collateral estoppel came to provide for conclusive effect of government judgments, that such effect should not be foreclosed.

\section{A. Enactment of a Prima Facie Presumption in 1914}

The legislative history surrounding the enactment of the Clayton Act in 1914, taken by itself, supports the view that applying offensive collateral estoppel to judgments obtained in government enforcement actions would be consistent with congressional intent. The original purpose of $\S 5$ of the Clayton Act was to help private plaintiffs recover treble damages for violations of the antitrust laws.21 Prior to 1914, private antitrust actions had been few and unsuccessful, largely because of the great cost of antitrust litigation and the inequality in financial resources between potential plaintiffs and defendants. ${ }^{2: 2}$ To remedy this situation, President Wilson proposed that private individuals in-

19. Richfield Oil Corp. v. Karseal Corp., 271 F.2d 709, 723-27 (9th Cir. 1959), cert. denied, 361 U.S. 961 (1960) (error to instruct jury that facts proved in prior government judgment could not be rebutted by defendant); Purex Corp., Ltd. v. Procter \& Gamble Co., 308 F. Supp. 584, 589-90 (C.D. Cal. 1970), aff'd, 453 F.2d 288 (9th Cir. 1971), cert. denied, 405 U.S. 1065 (1972) (denial of offensive collateral estoppel against defendant who lost in prior government enforcement action); Michigan v. Morton Salt Co., 259 F. Supp. 35, 64-65 (D. Minn. 1966), aff'd sub nom. Hardy Salt Co. v. Illinois, 377 F.2d 768 (8th Cir.), cert. denied, 389 U.S. 912 (1967) (dictum); Harrison v. Paramount Pictures, Inc., 115 F. Supp. 312, 315, (E.D. Pa. 1953), aff'd, 211 F.2d 405 (3d Cir. 1954) (denial of plaintiff's motion for judgment n.o.v. because prior government judgment against defendants could not be given conclusive effect); Zuckerman v. E.I. DuPont de Nemours Co., 1953 Trade Cas. If 67,468 (S.D.N.Y. 1953) (denial of summary judgment on basis of prior government judgment against same defendant); Deluxe Theatre Corp. v. Balaban \& Katz Corp., 95 F. Supp. 983, 986-87 (N.D. Ill. 195I) (striking paragraphs in plaintiffs' complaint alleging prior government judgment as conclusive evidence).

20. E.g., Neuberger v. Commissioner, 311 U.S. 83, 88 (1940) (fact that Congress "has particularizcd instances where partncrship income retains its identity in the individual partner's return" does not preclude such retention of identity in other instances if there is "clear and contrary evidence of Congressional intent"); Massachusetts Trustees of $\mathrm{E}$. Gas \& Fuel Associates v. United States, 312 F.2d 214, 220 (1st Cir. 1963), aff'd, 377 U.S. 235 (1964) (statute providing that charterers of government vessels must pay the Maritime Commission a certain percentage of their profits does not necessarily preclude the Commission from charging a higher percentage).

21. S. Rep. No. 698, 63d Cong., 2d Sess. 10 (1914); H.R. Rep. No. 627, 63d Cong., 2d Sess. 14 (1914). See Hearings on S. 2512 Before the Subcomm. on Antitrust and Monopoly of the Senate Comm. on the Judiciary, 89th Cong., $2 \mathrm{~d}$ Sess. 3 (1966) [hereinafter cited as Hearings on S. 2512 (1966)]; S. REP. No. 619, 84th Cong., lst Sess. 3 (1955).

22. Hearings on S. 2512 (1966), supra note 21, at 2-3,61; S. REP. No. 619, supra note 21, at 3; 51 CoNG. REc. 16046 (1914); Hardy, The Evisceration of Section 5 of the Clayton Act, 49 Gro. L.J. 44, 45-47 (1960). 
jured by violations of the antitrust laws be given "the right to found their suits for redress upon the facts and judgments proved and entered in suits by the Government." 23 Congress responded the same year with $\$ 5$ of the Clayton Act. ${ }^{24}$ The legislative history indicates that in 1914 Congress would have given conclusive rather than prima facie effect to government judgments but for the fear that a conclusive presumption would be unconstitutional. ${ }^{25}$ On the basis of this legislative history, commentators have argued that Congress intended the prima facie presumption to be the minimum effect given prior judgments, not the maximum. Where the common law has evolved to give conclusive effect to prior judgments against a defendant, the argument continues, $\$ 5(\mathrm{a})$ should not stand in the way. ${ }^{26}$

The crucial error in this legislative history argument, however, is that it assumes Congress has not dealt with the $\$ 5$ presumption since 1914.27 In fact, the legislative history of $\$ 5$ did not end in 1914. In 1955 Congress amended the Clayton Act to allow the United States to recover actual damages for injury suffered from antitrust violations. ${ }^{28}$

23. Trusts and Monopolifs, Address of the President of the United States Before tine Joint Session of Coxgress, H.R. Doc. No. 625, 63d Cong., 2d Sess. 8 (1914).

24. Ch. 323, \$ 5, 38 Stat. 731 (1914) (codified in 15 U.S.C. $\$ 16$ (1970)). See H.R. REP. No. 627, supra note 2I, at 14; Minnesota Mining \& Mfg. Co. v. New Jersey Wood Finishing Co., 381 U.S. 311,318 (1965).

25. The House originally passed the Clayton Act with a provision that a government judgment would "constitute against such defendant conclusive evidence of the same facts, and be conclusive as to the same questions of law in favor of any other party." S. REP. No. 698, supra note 21, at 57-58. See H.R. REP. No. 627, supra note 21, at 2. The Senate Judiciary Committee thought there were "considerations of public policy which favor the House provision of conclusiveness," but feared that denying a defendant his day in court against a new opponent would violate his right to due process of law. $S$. Rer. No. 698, supra note 21, at 45 . This fear dominated the Senate debates on $\$ 5$, see 51 CoNG. Rec. 13851-57, 13898-90I, 15824, 15938 (1914), and the Senate adopted a prima facic presumption. After a conference committee, the House accepted the Senate version because of the same concern that a provision for conclusive effect would be unconstitutional. See 51 CoNG. Rec. 16276 (1914); Langsdorf, supra note 15, at 206-09.

The congressional fears were unfounded. They resulted from a confusion of two doctrines: the constitutional requirement of due process of law-that a defendant must have his day in court before an issue is decided against him-and the judge-made requirement of mutuality of estoppel-that unless both parties are bound by a prior judgment, neither may use the judgment as determinative of an issue in a subsequent action. The due process requirement is satisfied by the opportunity of the antitrust defendant to litigate the issues against the Government. The rule of mutuality was never a constitutional requirement, but only a common law rulc. iB Moore's Federal Practice, supra note 5, f 0.412 at 1801-12; Langsdorf, supra note 15 , at 208 n.60. See BlonderTongue Laboratories, Inc. v. University of Ill. Foundation, 402 U.S. 313, 320-27 (1971).

26. Langsdorf, supra note 15, at 206-10; Note, supra note 13, at 81-84; Note, supra note 15 , at $1346 \&$ n.45.

27. The authors of Note, supra note 13, and Note, supra note 15, do not take into account congressional consideration of $\$ 5$ after 1914. Although Langsdorf, supra note 15, considers subsequent congressional action on $\$ 5$, he misconstrues it. See note 37 infra.

28. Act of July 7, 1955, Pub. L. No. 137, § 1, 69 Stat. 282-83 (1955) (codified in 15 US.C. $\S 15 \mathrm{a}(1970))$. Congress enacted $\S 4 \mathrm{~A}$ of the Clayton Act in 1955 to allow the 
At the same time, Congress reenacted as $\S 5$ (a) the provision that a government enforcement judgment would have prima facie effect in a subsequent private treble damage action; in its reenactment, Congress also added a provision giving a prior government enforcement judgment the same prima facie effect in the newly-created government damage action. ${ }^{29} \mathrm{~A}$ subsequent legislative effort to make the presumption conclusive failed in 1966.

\section{B. Congressional Consideration of a Conclusive Presumption in 1955 and 1966}

Congress reenacted the prima facie standard of $\S 5$ in 1955 despite specific proposals to make the presumption accorded to government judgments conclusive. The 1955 amendments to the Clayton Act were first introduced in 1950 as part of a bill (H.R. 7905) that would also have changed $\S 5$ 's presumption to a conclusive one. ${ }^{30}$ In that year, the House Subcommittee on Antitrust held hearings on the desirability of making $\S 5$ 's presumption conclusive, ${ }^{31}$ and decided that the prima facie standard should be retained. The subcommittee heard testimony about the history of the prima facie presumption and the advantages of changing it to a conclusive one. ${ }^{32}$ Witnesses testified against a conclusive presumption, but, unlike in 1914, no one questioned its constitutionality. ${ }^{33}$ The committee members themselves had policy objections to the change. ${ }^{34}$ The Judiciary Committee reported out, and the

United States to recover damages when "injured in its business or property by reason of anything forbidden in the antitrust laws." The amendment followed a supreme Court decision that the United States was not a "person" who could recover damages under $\$ 4$ of the Clayton Act, 15 U.S.C. $\$ 15$ (1970). United States v. Cooper Corp., 312 U.S. 600 (1941).

29. Act of July 7, 1955, Pub. L. No. 137, § 2, 69 Stat. 283 (1955). For the text of $\S 5(a)$, see note 2 supra.

30. H.R. 7905, 8lst Cong., 2d Sess. (1950).

31. Hearings on H.R. 7905 (H.R. S763) Before the Subcomm. on the Study of Monopoly Power of the House Comm. on the Judiciary, 8lst Cong., 2d Sess., ser. 14, pt. 5 (1950) [hereinafter cited as Hearings on H.R. 7905 (1950)].

32. Id. at $2-4,11,12,18,47,65$. The prima facie presumption of $\$ 5$ also had been criticized in the legal literature. W. Hamilton \&. I. Till, ANTirrust IN Acrion 83 (TNEC Monograph 16, 1940); Note, Antitrust Enforcement by Private Parties: Analysis of Developments in the Treble Damage Suit, 61 YaLe L.J. 1010, 1040 (1952); Note, Clayton Act, Section 5: Aid to Treble Damage Suiters?, 61 YALE L.J. 4I7, 425-26 (1952). But sec Note, Government Antitrust Judgments as Evidence in Private Actions, 65 Harv. L. REv. 1400, 1407 (1952) (conclusive presumption in $\$ 5$ would prolong government litigation and help plaintiffs no more than a prima facie presumption).

33. Hearings on H.R. 7905 (1950), supra note 31, at 52-53, $89-90$; Sce id. at 68 (statement submitted to Committec). The only mention of a potential constitutional problem is in a statement and a letter in the appendix to the printed Hearings. Id. at 89 , 97. The issue was mentioned in neither the subcommittee hearings, nor the Judiciary Committee's Report on the bill. See H.R. REP. No. 2467, 8Ist Cong., 2d Sess. (1950).

34. Committce members believed that a defendant who lost in a government suit should have an opportunity to relitigate his case against a different opponent and 
House passed, a bill which retained the prima facie presumption. ${ }^{35}$ The measure failed to reach the Senate floor in 1950 and was reintroduced in each Congress until 1955 when it became law. After the Judiciary Committee rejected the proposal for a conclusive presumption, each bill introduced to accomplish the other purposes of H.R. 7905 provided for a prima facie presumption. ${ }^{36}$ Hence the reenactment of $\S 5$ reflected a congressional preference for the prima facie rather than the conclusive presumption, not a concern that the latter would be unconstitutional. ${ }^{37}$

In 1966, as part of a legislative effort to give presumptive effect to nolo contendere pleas, Congress considered another proposal to make the $\$ 5(\mathrm{a})$ presumption conclusive. ${ }^{38}$ The Antitrust and Monopoly Sub-

feared that a conclusive presumption would pressure businessmen to settle every government suit by a consent decree. (The $\$ 5$ presumption does not apply to a settlement by consent decree. 15 U.S.C. $\$ 16($ a) (1970). See note 79 infra; Hearings on H.R. 7905 (1950), supra note 31 , at $5-13$.

35. H.R. 8763, 81st Cong., 2d Sess. (1950). See H.R. REP. No. 2467, supra note 32; 96 Cong. Rec. 10437-44 (1950).

36. See H.R. 3408, H.R. 1323, 82d Cong., 1st Sess. (1951); H.R. 467, 83d Cong., 1st Sess. (1953); H.R. 655, H.R. 794, H.R. 3658, H.R. 4954, 84th Cong., Ist Sess. (1955). H.R. 4954 was enacted into law in 1955. Act of July 7, 1955, Pub. L. No. 137, 69 Stat. 282 (1955).

37. When Congress enacted the prima facie standard in 1955 , no question was raised about the constitutionality of a conclusive presumption. See S. REP. No. 619, supra note 21; H.R. Rep. No. 422, 84th Cong., Ist Scss. (1955); 101 Cong. Rec. 5129-34, 9165-66 (1955); Hearings on H.R. 365 S Before the Subcomm. on the Study of Monopoly Power of the House Judiciary Comm., 84th Cong., 1st Sess. (1955) (unpublished, portions on file with the Yale Law Journal) [hereinafter cited as Hearings on H.R. 365 S (1955)]. (Hearings on H.R. 3658 (1955) can be considered part of the legislative history of the 1955 amendments. H.R. 3658 contained provisions identical to those in the bill ultimately enacted (H.R. 4951); it was authored by the same Congressman (Rep. Celler) and introduced in the same session. The hearings were held before the Antitrust Subcommittee of the House Judiciary Committe only two months before the same committee reported H.R. 4951 to the House.)

The 1955 reenactment has special bearing on the argument that Congress made the $\$ 5$ presumption prima facic only because it thought a conclusive presumption would be unconstitutional. One proponent of the argument that Congress intended the prima facie presumption to be the minimum rather than the maximum effect given to government judgments discusses the 1955 reenactment but misconstrues its history. Langsdorf, supra note 15, at 209 . He states that in 1914, convinced by a "tortuous line of reasoning" that a conclusive presumption would be unconstitutional, Congress "reluctantly adopted the prima facie evidence doctrine." He then asserts that "history repeated itself in 1955 " because H.R. 7905 had provided for a conclusive presumption (p. 550 supra) that was inexplicably deleted when the bill was reintroduced the next year. Langsdorf, supra at 209. This analysis ignores the fact that a House subcommittee considered the merits of H.R. 7905's conclusive presumption and reported out the bill with a prima facie standard. See pp. 550-51 supra.

38. S. 2512, 89th Cong., 2d Sess. (1966). The nolo contendere plea, by which a criminal defendant neither contests nor admits his guilt, is frequently entered in criminal antitrust cases. The plea is particularly attractive to antitrust defendants because courts have construed the proviso against giving prima facie effect under $\$ 5$ (a) to consent decrees as also applying to nolo contendere pleas. E.S., Burbank v. General Elec. Co., 329 F.2d 825, 830-35 (9th Cir. 1964); Twin Ports Oil Co. v. Pure Oil Co., 26 F. Supp. 366, $370-79$ (D. Minn. 1939), aff'd on other grounds, 119 F.2d 747 (Sth Cir.), cert. denied, 314 U.S. 664 (1941). S. 2512 would have prevented criminal antitrust defendants from using the nolo 
committee of the Senate Judiciary Committee held hearings on the question, and witnesses assured the Senators of both the need for and the constitutionality of a conclusive presumption. ${ }^{39} \mathrm{But}$ as in 1950 the change died in committee, and once again when the bill was reintroduced in subsequent Congresses, a prima facie presumption was substituted for the conclusive one. ${ }^{40}$

\section{Congressional Preemption of Common Law Collateral Estoppel in 1955}

When Congress amended $\S 5$ in 1955, it provided that a judgment in a government enforcement suit would have only prima facie effect in a subsequent government damage suit."1 In 1955, it was "well established" that after the United States obtained a criminal or civil judgment against a defendant, it could assert collateral estoppel against the same defendant in a subsequent government action. ${ }^{42}$ Absent the congressional amendment, the common law of collateral estoppel would have given conclusive effect to government judgments in subsequent government damage actions. By specifying in $\S 5(a)$ that

contendere plea to avoid the presumptive effect of $\$ 5$ (a) by making such pleas conclusive evidence in subsequent private damage actions against the same defendant. For a detailed discussion of. S. 2512, see Note, supra note 15.

39. Hearings on S. 2512 (1966), supra note 21 , at 9, 10,16,17,23, 30. Courts and commentators had continued to criticize the prima facie presumption of $\$ 5(a)$ after its reenactment in 1955. E.g., Minnesota Mining \& Mfg. Co. v. New Jersey Wood Finishing Co., 381 U.S. 311, 319 (1965); Michigan v. Morton Salt Co., 259 F. Supp. 35, 65 (D. Minu. 1966), aff'd sub. nom. Hardy Salt Co. v. Illinois, 377 F.2d 768 (8th Cir.), cert. denicd, 389 U.S. 912 (1967); Loevinger, Private Action-The Strongest Pillar of Antitust, 3 ANrrrust Bull. 167, 174-75 (1958); Comment, Proposed Amendment to Section 5(a) of Clayton Act Would Increase Evidentiary Aid for Subsequent Litiganls, 39 N.Y.U. L. REv. 518, 524-27 (1964). For criticism of the prima facie standard by commentators before its reenactment, see note 32 supra.

40. See S. 2157, 91 st Cong., 1st Sess. (1969); S. 1538, 90th Cong., 1st Scss. (1967).

41. Act of July 7, 1955 , Pub. L. No. 137, $\S 2,69$ Stat. 283 (1955) (codified at 15 U.S.C. $\$ 16(a)(1970)$ ) (A final judgment in a government enforcement suit "shall be prima facie evidence against such defendant in any action or proceeding brought by ... the United States under section $4 \mathrm{~A}$....")

42. Emich Motors Corp. v. General Motors Corp., 340 U.S. 558, 568-69 (1951) (dictum). See Sunshine Coal Co. v. Adkins, 310 U.S. 381, 402-03 (1910) (judgment sustaining determination by United States Bituminous Coal Commission is res judicata in sub. sequent action by Internal Revenue Service; "[t]he crucial point is whether or not in the earlier litigation the representative of the United States had authority to represent its interests in a final adjudication of the issue in controversy."); United States v. Munsingwear, 340 U.S. 36 (1950) (judgment against United States in injunctive action for viola. tion of price control regulation estops the Government in subsequent suit for damages against same defendant); Local 167, Teamsters v. United States, 291 U.S. 293, 298-99 (1934) (criminal conviction under Sherman Act estops defendants in subsequent government injunctive suit); United States v. Standard Ultramarine \& Color Co., 137 F. Supp. 167, 174 n.32 (S.D.N.Y. 1955) (dictum); United States v. Ben Grunstein \& Sons Co., 127 F. Supp. 907, 911 (D.N.J. 1955) (guilty plea in criminal prosecution for violation of the False Claims Act estops defendant in subsequent civil action by the United States to recover damages). 
those judgments should receive prima facie effect, Congress overrode the existing common law.

In United States $v$. Grinnell Cor $p .,^{43}$ the court held that $\$ 5(a)$ bars the use of common law collateral estoppel in a government damage suit against a defendant who has lost in a prior government enforcement suit. In that case, the United States sought damages from defendants previously found liable in a Sherman Act enforcement action." The court noted that "under established common law principles of collateral estoppel," the defendants would have been estopped from relitigating their violation of the antitrust laws, but reasoned from the 1955 amendment that

Congress must have meant to limit the use of an enforcement action judgment by the United States in later damage suits by making it no more than prima facie evidence of antitrust violations. Any other reading makes the added phrase mere surplus verbiage, because, absent the phrase, the enforcement judgment would have conclusive effect under the doctrine of collateral estoppel in a private government suit against the defendant. ${ }^{45}$

By overriding the conclusive effect which would have been given under existing common law collateral estoppel to government enforcement judgments in subsequent government damage actions, the 1955 amendment necessarily preempted future developments in the common law. Congress intended government damage actions to function in the same way as private damage actions, ${ }^{46}$ because the government sues for damages not in its role as enforcer of the law but as if it were a private plaintiff. ${ }^{47}$ The $\S 5(a)$ presumption is no exception;

43. 307 F. Supp. 1097 (S.D.N.Y. 1969).

44. United States v. Grinnell Corp., 236 F. Supp. 244 (D.R.I. 1964), aff'd in part and remanded in part, 384 U.S. 563 (1966).

45. 307 F. Supp. at 1097-98. Langsdorf, supra note 16, who criticizes the Grinnell decision but concedes that Congress must amend $\$ 5(a)$ before courts may use a government enforcement judgment to estop a defendant in a subsequent government damage suit. Id. at 212.

46. Where Congress intended the government damage action to be treated differently from the private damage action, it was explicit. For cxample, Congress authorized the United States to recover only actual damages rather than the treble damages a private plaintiff may recover, because the Government does not need treble damages as an incentive to suc. "The difference in treatment is a recognition of the difference in the position of the United States and of 'persons' in this connection." S. REP. No. 619, supra note 21 , at 3 .

47. S. Rep. No. 619, supra note 21, at 3 ("The proposed legislation, quite properly, treats the United States solcly as a buyer of goods . . ."); H.R. REP. No. 422, supra note 37, at I-5. See Hawaii v. Standard Oil Co., 405 U.S. 25I, 265 (1972); International Tel. \& Tel. Corp. v. General Tel. \& Elec. Corp., 369 F. Supp. 316, 327 (M.D.N.C. 1973); H.R. RrP. No. 1130, 90th Cong., 2d Sess. 5 (1968); S. ReP. No. 454, 90th Cong., 1st Sess. 6 (1967); Letter from Ramsey Clark to Emanuel Celler (Jan. 7, 1966), reprinted in S. RER. 
section 5(a) treats government and private damage actions alike.48 Given that $\S 5$ (a) preempted common law developments in collateral estoppel which would give government enforcement judgments conclusive effect in subsequent government damage actions, it follows that $\$ 5(a)$ also preempted developments which would give those judgments conclusive effect in subsequent private damage actions. To allow offensive collateral estoppel in private treble damage actions would frustrate the congressional purpose of giving prima facie effect to judgments obtained in government enforcement actions even where the common law would give conclusive effect.

\section{The Effect of Prior Private Judgments}

\section{A. Statutory Preemption: Effect of Government Damage Judgments}

Even if it is established that $\$ 5(\mathrm{a})$ precludes giving conclusive effect to judgments obtained in government enforcement actions, the question remains whether the statute precludes giving conclusive effect to judgments obtained in private treble damage actions. As with the effect of government judgments under $\$ 5$ (a), preclusion would follow from the principle of expressio unius est exclusio alterius: just as the specification of the prima facie standard for government judgments implies that only prima facie effect may be given, ${ }^{40}$ so the provision for the presumptive effect of government judgments implies that only government judgments may be given such effect. And if judgments in private suits may not be given prima facie effect, they may not be given conclusive effect through offensive collateral estoppel. At least

No. 454, supra at 9-11; Hearings on H.R. 3658 (1955), supra note 37, at 7; Hearings on H.R. $340 s$ Before the Subcomm. on Study of Monopoly Power of the House Comm. on the Judiciary, 82d Cong., Ist Sess. 3 (1951) [hereinafter cited as Hearings on H.R. $340 S$ (195I)]; Hearings on H.R. 7905 (1950), supra note 31, at 18-20, 43, 63-65.

48. Section 5(a) makes a prior government judgment prima facie cvidence in "any action or proceeding brought by any other party ... or by the United States" in a government damage action. 15 U.S.C. $\$ 16 a$ (1970). Testifying in 1955 on a bill containing provisions identical to those enacted later in the session, Stanley Barnes, head of the Justice Department's Antitrust Division, observed that the prima facie effect given in $\$ 5$ (a) to government enforcement actions in subsequent government damage actions

places the United States in the same category as the private litigant in relying upon the action by the United States, not in a proprietary capacity, but in an enforcement capacity in obtaining a judgment against a private individual.

Hearings on H.R. 365 S (1955), supra note 37, at 7. See Hardy Salt Co. v. Illinois, 377 F.2d 768, 771 (8th Cir. 1967) ("Congress in 1955 amended Section 5 of the Clayton Act . . . to provide that final judgment or decrees in government actions under the antitrust laws would be prima facie evidence in damage suits by the United States as well as in private damage suits.")

49. See p. 547 supra. 
one court has refused to apply collateral estoppel to a judgment in a private damage action on the ground that Congress wanted only judgments in government enforcement suits to have presumptive effect in subsequent antitrust actions by third parties. ${ }^{50}$ But once again the 1955 amendments to $\$ 5$ provide even stronger evidence that Congress intended to deny conclusive effect to private judgments.

In those amendments Congress added a proviso to $\$ 5$ which makes the prima facie presumption inapplicable to judgments obtained in government damage actions. ${ }^{51}$ The implications of this proviso are straightforward. Courts cannot give conclusive effect through collateral estoppel to judgments in government damage suits when Congress has explicitly refused to give even prima facie effect to such judgments. Since Congress intended that private treble damage actions and government damage actions be treated alike, courts similarly cannot give conclusive effect through collateral estoppel to a judgment obtained in a private damage suit. ${ }^{52}$

\section{B. Statutory Policy: Primacy of the Government Enforcement Action}

The denial of prima facie effect to government damage judgments in $\$ 5$ (a) reflects the congressional policy that government enforcement actions should play a more important role than damage actions, whether government or private, in enforcing the antitrust laws. Congress has given enforcement suits this primary role because it intended that such suits be brought only in the public interest-specifically, to preserve and promote competition in the economy. ${ }^{53}$ The Antitrust Division of the

50. Levin v. IBM, No. 1173.72, slip op. at 4-5 (D.N.J., Jan. 17, 1974) (denying plaintiff's motion for pretrial summary judgment). See note 12 supra.

51. "Provided, That this section shall not apply to ... judgments or decrees entered in actions under section 15a of this title." 15 U.S.C. $\$ 16$ (a) $(1970)$.

52. See pp. 553.54 supra.

The reasoning of Part II $(A)$ would apply with equal force to the unlikely case in which the Justice Department asserts offensive collateral estoppel against a defendant who has lost in a prior private treble damage suit. See note 12 supra.

53. "The Supreme Court has said repeatedly [that] the antitrust law has its own standard of the public interest; namely, the preservation and promotion of competition." Hearings on $S$. $7 S 2$ Before the Senate Subcomm. on Antitrust and Monopoly of the Senate Comm. on the Judiciary, 93d Cong., 1st Sess. 420 (1973) [hereinafter cited as Senale Consent Decree Hearings (1973)] (testimony of Professor Donald Turner, former head of the Antitrust Division).

Of course the Antitrust Division may not always serve the public interest adequately. But where such indications have come to the attention of Congress, it has responded with legislation to reform Antitrust Division procedures so that the public interest will be better served. Recently, in the wake of the controversy over the settlement of the Justice Department suit to enjoin the IT'T acquisition of the Hartford Fire Insurance Company (United States r. International Tel. \& Tel. Corp., 349 F. Supp. 22 (D. Conn. 1972)), Congress enacted the Antitrust Procedures and Penalties Act, which provides for judicial supervision of Justice Department consent decrecs to ensure that they are in the public 
Department of Justice ${ }^{5-4}$ is expected to consider the effect of a suit on defendants, potential plaintiffs, and competitive conditions generally. ${ }^{55}$ It devises a coordinated program of antitrust enforcement, ${ }^{, b}$ and its limited resources force it to bring only those suits which will most effectively promote the goal of preserving competition. ${ }^{57}$ Congress intended the private treble damage suit to supplement the Government's enforcement effort; ${ }^{5 s}$ it never intended the treble damage suit to be brought in the public interest. The purpose of providing treble damages in private suits was to motivate private litigants to

interest. Pub. L. No. 93-528, $\$ \S 2(d)(1)$, (2), 88 Stat. 1706 (1974) (codified in 15 U.S.C. \$ 16(c) (Supp. IV 1976)). See S. Rer. No. 298, 93d Cong., 1st Sess. 5 (1973); H.R. Rer. No. 1463, $93 \mathrm{~d}$ Cong., $2 \mathrm{~d}$ Sess. 6-8 (1974); Hearings on $S .7 \$ 2$ Before the Subcomm. on Monopoly and Commercial Law of the House Comm. on the Judiciary, 93d Cong., Ist Sess. 35, 38, 165, 180, 190 (1973) [hereinafter cited as House Consent Decree Hearings (1973)]; Senate Consent Decree Hearings (1973), supra at $64,69,147,163$. Whether or not the government enforcement agencies actually do bring suits in the public interest, the important point for the argument of this Note is that Congress intended them to do so, and accordingly has given them a primary role in enforcing the antitrust laws.

54. The Federal Trade Commission (FTC) is the other government agency charged with enforcing the antitrust laws. See 15 U.S.C. $\$ 21$ (1970) (FTC may issue cease and desist orders to enforce compliance with $\$ \$ 2,3,7,8$ of the Clayton $A c t)$. Like the Justice Department, the FTC is expected to bring enforcement proceedings "in the public interest." New Jersey Wood Finishing Co. v. Minnesota Mining \& Mfg. Co., 332 F.2d 346, 353 (1964), aff'd, 381 U.S. 311 (1965).

55. See Antitrust Procedures and Pcnaltics Act, Pub. I. No. 93-528, $\$ 2(d)(1),(2), 88$ Stat. 1706 (codified in 15 U.S.G. $\$ 16($ e) (Supp. IV, 1974)) (in settling enforcement actions by consent decree, Justice Department must consider impact of settlement upon competition, public generally, and individuals alleging specific injury from the alleged violation).

For example, the Antitrust Division attempts to ensure that a government suit will not actually reduce competition by forcing the defendant out of business. See Address by Baddia J. Rashid, Antitrust Division Director of Operations, Before the National Institute on Government Antitrust Enforcement, Nov. 11, 1972, in $5 \mathbf{C C H}$ TrAdE REg. Rep. ? 50,154 , at $55,263(1975)$. It also uses economic analysis to evaluate the competitive impact of possible violations, see Address by Richard W. McLaren, Northwestern University Law School 8th Annual Corporate Counsel Institute, Oct. 8, 1969, in 5 CCH Tride REG. REP. If 50,258, at 55,539-42 (1975), and it is sensitive to the larger implications of the legal theory a court adopts in its decision. See Senate Consent Decree Hearings (1973), supra note 53, at 194-95. Cf. H.R. REP. No. 1463, supra note 53, at 13 .

56. McLaren, supra note 55. See Report of Attorney General's National CommitteE To Study The Antitrust Laws 386 (1955) (Statement of Eugene V. Rostow).

57. Hearings on S. 2512 (1966), supra note 21, at 49; Posner, Exclusionary Practiccs and the Antitrust Laws, 41 U. CHI. L. REv. 506, 523 (1974). See House Consent Decree Hearings (1973), supra note 53, at 83; StafF of ANTITrust Subcomm. OF the House Comm. on the Judiciary Report on Conseit Decree Progrim of the Departalent of JUstice, 86th Cong., 1st Sess., $23-24$ (1959) [hereinafter cited as Consent Decree Report (1959)]; Hearings on H.R. 3408 (1951) supra note 47 , at 42.

Not all antitrust violations have an equal impact on competition, nor do all antitrust suits. There is a continuum extending from suits which are very important to preserving or achieving competition to those which actually result in harm to competition. Sec Rashid, supra note 55.

58. Bicks, The Department of Justice and Private Treble Damage Actions, 4 ANTITRUST BulL. 5, 8 (1959); Wham, Antitrust Treble Damage Suits: The Government's Chicf Aid in Enforcement, 40 A.B.A.J. 1061, 1061 (1954); Note, Fifly Years of Sherman Act Enforcement, 49 YALE L.J. 284, 296 (1939). 
sue in their own self-interest..99 Because damage actions bear no necessary relation to the public interest, government enforcement suits are the most important means for obtaining a rational antitrust policy. ${ }^{\circ 0}$

The courts have long recognized the preferred position of government enforcement suits under the antitrust laws. In 1925, the Supreme Court denied a private party standing to enforce a decree obtained by the Government to dissolve a combination, because the "United States

59. S. Rer. No. 619, supra note 21, at 3; Perma Life Mufflers, Inc. v. International Parts Corp., 392 US. 134, 139 (1968); Lawlor v. National Screen Serv. Corp., 349 U.S. 322 , 329 (1955). Courts and commentators have noted that private treble damage plaintiffs are motivated by economic self-interest. Minnesota Mining \& Mfg. Co. v. New Jersey Wood Finishing Co., 381 U.S. 311,318 (1965); United States v. Borden Co., 347 U.S. 514, 518 (1954); Bruce's Juices, Inc. v. American Can Co., 330 U.S. 743, $751-52$ (1947); Renfrew, Negotiation and Judicial Scrutiny of Setlements in Civil and Criminal Antitrust Cases, 57 CHI. B. Record 130, 134 (1975). The legislative history of the 1974 Antitrust Procedures and Penalties Act provides clear evidence that Congress recognizes the different nature of damage suits motivated by private self-interest and government suits brought in the public interest. See H.R. REP. No. 1463, supra note 53, at 11; S. REP. No. 298, supra note 53 at 6; House Consent Decree Hearings (1973), supra note 53, at 85; Senate Consent Decree Hearings (1973), supra note 53, at 21, 91, 116, 134, 148, 194, 200. Despite recognition of the great importance of certain private treble damage suits, House Consent Decree Hearings (1973), supra note 53, at 168, and suggestions that private as well as government settlements should be regulated, Senate Consent Decree Hearings (1973), supra note 53, at 63-61, Congress deliberately excluded private settlements from the scope of the Act, see House Consent Decree Hearings (1973), supra note 53, at 44; 15 U.S.C. $\$ 16$ (Supp. IV, 1974).

60. Professor Donald Turner, former head of the Antitrust Division, testified in 1973:

If you ask me are there any Supreme Court decisions that I think were wrongly

decided or were highly questionable in the last 10 years, I would say yes, and every one of them is a private law suit.

....

Here is the problem: The private antitrust lawyer's job . . . is to win a case for

his client any way he can, legitimately; that is by any kind of argument he can make.

He has no inhibitions . . . about trying all kinds of theories, of making use of all

kinds of past decisions, whether those past decisions made any sense or not.

His job is to get the most for his client that he can.

It seems to me that the kind of antitrust law you get out of that kind of an approach is not likely to be a highly rational antitrust law.

....

But the Antitrust Division at least, unlike the private plaintiffs, is not in the position of saying to itsclf, "Should we file a case just because we can win it; and when we do file a case, should we try to win it any way we can?"

$A$ responsible Government agency does not do that. It does not bring a case that it really thinks, as a matter of rational antitrust, should not be brought.

And when it brings the case, if it is operating properly, it does not try that case on any kind of kooky theory that might possibly win.

... [M]y firm belief is that for better or worse, we are much more likely to get rational antitrust policy and rational antitrust decisions if the main laboring oar is carried by the Department of Justice and the Federal Trade Commission.

Senate Consent Decree Hearings (1973), supra note 53, at 194-95.

Other commentators have questioned whether private treble damage actions promote a rational antitrust policy. E.g., Breit \& Elzinga, Antitrust Enforcement and Economic Efficiency: The Uneasy Case for Treble Damages, I7 J. Law \& Econ. 329 (1974); Posner, supra note 58, at 521-23, 535; Renfrew, supra note 59, at 134. 
... must alone speak for the public interest."61 This philosophy was reiterated in United States $v$. Borden $\mathrm{Co}^{62}$ In that case a federal district court had dismissed a government suit seeking an injunction against conduct already enjoined in a private suit. In reversing the lower court, the Supreme Court stated:

The private-injunction action, like the treble-damage action under $\$ 4$ of the Act, supplements government enforcement of the antitrust laws; but it is the Attorney General . . . who [is] primarily charged by Congress with the duty of protecting the public interest under these laws. The Government seeks its injunctive remedies on behalf of the general public; the private plaintiff . . . may be expected to exercise [his right to an injunction] onfy when his personal interest will be served. ${ }^{63}$

Courts have frequently denied private litigants the right to intervene in government enforcement suits, on the ground that "the private litigant [is] apt to confuse the public interest with his private interest." 64 Courts are also less inclined to bar a government enforcement action by res judicata than to bar a private suit, because the former is brought in the public interest. ${ }^{65}$

The provisions in $\$ 5($ a) of the Clayton Act exemplify this broad congressional purpose to rely most heavily on suits brought in the public

61. Buckeye Coal \& Ry. v. Hocking Valley Ry., 269 U.S. 42, 49 (1925).

62. 347 U.S. 514 (1954)

63. 347 U.S. at 518. The Court continued with a quotation from United States v. Bendix Home Appliances, I0 F.R.D. 73, 77 (S.D.N.Y. 1949):

"[T]he scheme of the [antitrust] statute[s] is sharply to distinguish between Government suits, either criminal or civil, and private suits for injunctive relief or for treble damages. Different policy considerations govern each of these."

347 U.S. at 518-19.

64. United States v. Shubert, 305 F. Supp. 1288, 1292 (S.D.N.X. 1969):

"The government is representing the public interest and it would be destructive of antitrust enforcement to allow a third party who has private litigation pending against some of the parties to the consent decree to inject himself into this litigation. The government is in a better position to determine what serves the public interest best, the private litigant being apt to confuse the public interest with his private interest."

$I d$. (quoting “Judge Kaufman's memorandum opinion in this case dated March 24, 1960"). See, e.g., Sam Fox Publishing Co. v. United States, 366 U.S. 683, 689 (1961); United States v. CIBA Corp., 50 F.R.D. 507, 513 (S.D.N.Y. 1970); cases cited in Handler, supra note 13 , at 18 n.92. However, courts have allowed intervention when the Government fails to represent the public interest. E.g., Cascade Natural Gas Corp. v. El Paso Natural Gas Co., 386 U.S. 129 (1967) (State of California had a right to intervene in settlement of government suit), discussed in Handler, supra note 13, at 17-23; United States v. First Nat'l Bank \& Trust Co., 280 F. Supp. 260, 263 (E.D. Ky. 1967), aff'd mem. sub nom., Central Bank \& Trust Co. v. United States, 391 U.S. 469 (1968).

65. Compare United Shoe Machinery Corp. v. United States, 258 U.S. 45I, 459-60 (1922) (successive suits by Government against same defendant under Sherman and Clayton Acts) with International Tel. \& Tel. Corp. v. General Tel. \& Elec. Corp., 369 F. Supp. 316, 326-27 (M.D.N.C. 1973) (successive suits by private plaintiff against same defendant for injunctive relief and damages). 
interest for effective enforcement of the antitrust laws. When Congress enacted $\$ 5$ in 1914, nothing prevented it from giving prima facie effect to judgments returned in private damage actions. Indeed, if the purpose of $\$ 5$ were to aid private plaintiffs in any way possible, as some commentators have suggested, ${ }^{66}$ there would have been no reason not to give prima facie effect to judgments obtained in private as well as government actions. Although there had not been many successful private damage actions prior to 1914 , there had been some, ${ }^{67}$ and including private judgments under $\$ 5$ certainly would have helped private plaintiffs. Inclusion also would have encouraged defendants to settle with private plaintiffs in order to avoid the prima facie presumption in subsequent suits, just as they are now encouraged to settle with the Government in enforcement suits. ${ }^{68}$ Nonetheless, Congress gave private plaintiffs the right to base their suits only on judgments in government enforcement suits. ${ }^{60}$ Similarly, in 1955 Congress declined to give prima facie effect to government damage judgments, recognizing that government damage actions, like private damage actions, were not meant to be brought in the public interest. ${ }^{70}$

The prima facie effect given to a government enforcement judgment "magnifies" that judgment by encouraging private plaintiffs to use it to establish their own case. In making recovery by private plaintiffs easier, $\$ 5(a)$ increases the probability that an antitrust violation proved in a government enforcement action will give rise to treble damage recoveries. ${ }^{71}$ Those recoveries increase the penalty imposed on the violator and

66. Note, supra note 13, at 81-84; Note, supre note 15, at 1336-39.

67. See Hearings on S. 2512 (1966), supra note 21, at 180-88.

68. See Flynn, Consent Decrees in Antitrust Enforcement: Some Thoughts and Proposals, 53 Iowa L. Rev. 983, 987 (1968); p. 561 infra.

69. While there is no clear indication why Congress gave prima facie effect only to government judgments in 1914 , the congressional debates show that the legislators were mindful of the fact that government enforcement suits are brought in the public interest and private damage suits are not. 51 Cong. Rec. 9165, 16319 (1914) (remarks of Rep. Floyd); id. at 13851-52, 13898 (remarks of Sen. Walsh).

70. Congress amended $\S 5$ in 1955 to ensure that government damage actions would not be confused with government enforcement actions for the purposes of the $\$ 5$ (a) presumption. See Hearings on H.R. 3658, supra note 37 , at 7. John C. Stedman, representing the Antitrust Division, explained why prima facie effect should not attach to damage judgments:

[I]n any event, we feel the Government suit [under $\$ 4 A$ ] should be viewed as more analogous to the private remedial action than to the usual civil or criminal action brought for the benefit of the competitive economy as a whole. Consequently, recovery should not depend upon the fortuity of the Government's bringing or not bringing a suit for the damages accruing to it as a Government.

Hearings on H.R. 7905 (1950), supra note 31 , at 65.

71. Since the enactment of the Clayton Act, the bulk of private antitrust litigation has followed successful Government action, so that the judgments and decrees in the Federal proceeding could be used to establish a case.

S. Rrp. No. 619, supra note 21, at 3. See Posner, A Statistical Study of Antitrust Enforce- 
compensate more plaintiffs injured by the violation. By giving prima facie effect to government enforcement judgments but not to government or private damage judgments, Congress intended this magnification to occur only where the violation has been established in a suit brought in the public interest. ${ }^{72}$

Section 5 also magnifies the influence of government enforcement suits by providing that the statute of limitations for private antitrust actions is tolled while a government enforcement suit is pending. ${ }^{73}$ Like the $\S 5$ (a) presumption, the tolling provision encourages private plaintiffs to sue in the wake of enforcement suits. A plaintiff can benefit greatly by waiting until the end of a government enforcement suit to commence an action against the same defendant. Government litigation uncovers violations, collects and organizes evidence, forges new theories of antitrust liability, and schools subsequent plaintiffs in tested pleading and trial techniques. ${ }^{74}$ Tolling the statute of limitations while private or government damage suits are pending would give similar benefits to subsequent private plaintiffs and thus increase the influence of damage suits. ${ }^{75}$ Yet Congress has not chosen to enact a tolling provision for the private damage suit, and in the 1955 amend-

ment, 13 J. LAw \& Econ. 365, 372 (1970); Wheeler, Antitrust Treble Damage Aclions: Do They Work?, 61 CAL. L. REv. 1319, 1326 (1973); Timberlake, The Use of Government Judgments or Decrees in Subsequent Treble Damage Actions Under the Clayton Act, 36 N.Y.U. L. REV. 991 (196I).

72. Although the Supreme Court has never decided the issue, recent lower court decisions have held that an FTC order may be given prima facie effect under $\$ 5(a)$ as a “final judgment or decree." Purex Corp. v. Procter \& Gamble Co., 453 F.2d 288 (9th Cir. 1971), cert. denied, 405 U.S. 1065 (1972) (order enforced by court of appeals); Farmington Dowel Prods. Co. v. Forster Mfg. Co., 421 F.2d 61, 66-76 (Ist Cir. 1970) (final FTC order). But see id. at 67 \& nn.7 \& 8.

73. Whenever any civil or criminal proceeding is instituted by the United States to prevent, restrain, or punish violations of any of the antitrust laws, but not including an action under section 15a of this title, the running of the statute of limitations in respect of every private right of action arising under said laws and based in whole or in part on any matter complained of in said proceeding shall be suspended during the pendency thereof and for one year thereafter ....

15 U.S.C. $\S 16(i)$ (Supp. IV, 1974) (formerly 15 U.S.C. $\$ 16(b)$ (1970)). A plaintiff who takes advantage of this section must bring suit "within the period of suspension or within four years after the cause of action accrued." Id.

In Minnesota Mining \& Mfg. Co. v. New Jersey Wood Finishing Co., 381 U.S. 311 (1965), the Supreme Court held that the statute of limitations for private damage actions is tolled during the pendency of an FTC enforcement proceeding, just as it is tolled during a Justice Department suit.

74. Minnesota Mining \& Mfg. Co. v. New Jersey Wood Finishing Co., 381 U.S. 311 , 319 (1965); Hearings on H.R. 3408 (1951), supra note 47, at 5; Korman, The Antitrust Plaintiff Following in the Government's Footsteps, 16 VILL. L. REV. 57, $70-72$ (1970); Loevinger, Handling a Plaintiff's Antitrust Damage Suit, 4 Axtrrrust Bul. 29, 38 (1959). But cf. Hearings on S. 2512 (1966), supra note 21, at 91.

75. See Note, Antitrușt Enforcement by Private Parties, supra note 33, at 1043. 
ments to $\$ 5$ it made clear that the tolling provision did not apply to the nerwly-created government damage suit. ${ }^{\top 0}$

Congress's decision to allow private plaintiffs to benefit from government enforcement suits but not from damage suits is consistent with other procedural measures by which Congress has sought to enhance the effectiveness of government enforcement suits, even at the expense of private plaintiffs. When Congress enacted $\$ 5$ in 1914, it provided that the prima facie effect given to government enforcement judgments should not extend to consent decrees. ${ }^{77}$ The Antitrust Division settles the great majority of its suits by consent decree in order to use its limited resources efficiently. ${ }^{78}$ Government consent decrees are attractive to defendants because, unlike contested judgments, they are not prima facie evidence in subsequent treble damage actions; if they were, defendants would be much less likely to settle with the Government. ${ }^{79}$ To give prima facie effect to consent decrees as well as to judgments in litigated cases would help private litigants, but it would also obstruct government enforcement of the antitrust laws. Faced with this trade-off between efficiency of government enforcement and ease of private recovery, Congress opted for government efficiency by excluding consent decrees from $§ 5$ 's prima facie presumption. ${ }^{s 0}$ Recognizing that Congress intended the proviso to promote government antitrust enforcement, courts have given it an expansive interpretation. ${ }^{81}$

Congress has given government enforcement actions other important procedural advantages over private and government damage suits

76. Act of July 7, 1955, Pub. L. No. 137, $\$ 5$ (b), 69 Stat. 283 (codified in 15 U.S.C. $\S 16$ (i) (Supp. IV, 1974)).

77. I5 U.S.C. $\$ 16($ a) (1970) ("Provided, That this section shall not apply to consent judgments or decrees entered before any testimony has been taken . . . .")

78. See H.R. REP. No. 1463, supra note 53, at 6; S. REP. No. 298, supra note 53, at 5; Consent DeCReE Report (1959), supra note 57, at 7-10, 18-19; Flynn, supra note 68, at 983-84 \& n.1; Posner, supra note 71, at 375.

79. Hearings on S. 2512 (1966) supra note 21, at 95; CoNsENT DeCREE RePORT (1959), supra note 57, at 22-24. See H.R. REP. No. 1463, supra note 53, at 6; S. REP. No. 298, supra note 53, at 7; Consent DECREe RePORT (1959), supra note 57, at ix, 303; Hearings on S. 2512 (1966), at 15, 45; Flynn, supra note 68, at 985-87, 1003; Symposium: The Relationship Between Government Enforcement Actions and Private Damage Actions, 37 ANTITRUST L.J. 823, 843 (1968).

80. The original House version of the Clayton Act included consent decrees under $\$ 5$. However, once it was pointed out how this provision would affect Department of Justice enforcement, the bill was amended. Hearings on S. 2512 (1966), supra note 21, at 78. See H.R. REP. No. 627, 63d Cong., 2d Sess., pt. 2, at 9 (1914) (Minority Report); 51 CoNG. REc. 13,900.01 (1914).

81. Courts have interpreted the proviso making $\$ 5$ inapplicable to "consent judgments or decrees" as including nolo contendere pleas in criminal suits. E.g., Twin Ports Oil Co. v. Pure Oil Co., 26 F. Supp. 366 (D. Minn. 1939). This interpretation is not compelled by the statutory language, but courts cite the congressional purpose of encouraging defendants to settle with the Department of Justice without going to trial. Id. at 371; City of Burbank v. General Elec. Co., 329 F.2d 825, 835 (9th Cir. 1964). 
in addition to those given in $\$ 5$. The Multidistrict Litigation Act provides for consolidation of pretrial proceedings in federal civil actions pending in different judicial districts and having one or more common questions of fact. ${ }^{82}$ Although the legislation was designed to cope with the problems of multidistrict antitrust litigation, ${ }^{83}$ government enforcement suits were exempted ${ }^{s t}$ because Congress feared that allowing consolidation of enforcement suits would result in their delay. ${ }^{85}$ Government damage suits, on the other hand, were specifically included. ${ }^{\text {ss }}$ Similarly, in the 1974 Antitrust Procedures and Penalties Act, Congress provided that antitrust suits certified to be of general public importance must be "in every way expedited" at the district court level and may be appealed directly to the Supreme Court. However, only government enforcement suits may be so certified..$^{s 7}$

The unique role which Congress has assigned to the government enforcement suit would be undermined by applying offensive collateral estoppel to judgments obtained in private damage actions. ${ }^{88}$ Assuming

82. 28 U.S.C. $\$ 1407$ (1970).

83. H.R. Rep. No. 1130, 90th Cong., 2 d Sess. 2 (1968); S. Rep. No. 454, 90th Cong., Ist Sess. 3 (1967).

84. 28 U.S.C. $\$ 1407(\mathrm{~g})(1970)$.

85. H.R. REP. No. 1130 , supra note 83 , at 5; S. ReP. No. 454, supra note 83 , at 6 .

86. 28 U.S.C. $\$ 1407(\mathrm{~g})(1970)$. In re Antibiotic Drugs, 309 F. Supp. 155 (Jud. Pan. Multidist. Litig. 1970) (Government damage suit consolidated); McDermott, The Judicial Panel on Mfulti-District Litigation, 57 F.R.D. 215 (1972).

87. 15 U.S.C. $\$ \S 28,29$ (Supp. IV, 1974).

Congress first passed expediting legislation for government enforcement actions in 1903 . Expediting Act of 1903, ch. 544, 32 Stat. 823 (1903) (codified at 15 U.S.C. $\$ \$ 28,29$ (1970)) (appeal from every government enforcement action "will lie only to the Supreme Court"; government actions certified by Attorney General to be of general public importance to be heard by three judge court "at earliest practicable date ... [and] to be in every way expedited"). The Antitrust Procedures and Penalties Act amended the 1903 Act to eliminate the use of three-judge courts to hear expedited government cases, to allow review in the courts of appeals of district court rulings on government motions for pretrial injunctions, and to allow judgments in government enforcement suits to be appealed either to a circuit court of appeals or directly to the Supreme Court. H.R. REP. No. 1463, supra note 53, at 10-11. The expediting provisions are another example of congressional recognition of the primacy of government enforcement suits:

The exception provided for possible direct Supreme Court post-trial review of litigated government civil antitrust cases reflects legislative recognition of the Attorney General's responsibilities to coordinate national antitrust enforcement policies and the necessary discretion incident to this legislatively imposed responsibility; and, that public antitrust cases differ in nature sufficiently from private antitrust cascs and concerns to warrant providing the Attorney Gencral with possible direct Supreme Court p. at 11 .

88. Allowing the Government to take advantage of judgments in prior private suits by asserting offensive collateral estoppel in enforcement suits, see note 12 supra, would not undermine the primacy of those suits. As long as government enforcement suits are brought in the public interest, allowing cstoppel would be consistent with the underlying congressional policy of encouraging rational antitrust enforcement. Yet allowing cstoppel might tempt the Government to bring a suit in which it could rely on a private judgment, rather than a suit which would serve the public interest. Cf. Note, Appcllalc 
that $\$ 5(a)$ would permit judgments obtained in prior government enforcement actions to be given conclusive effect, giving judgments in prior private suits such effect would put government and private actions on an equal footing. The congressional policy reflected in $\$ 5(\mathrm{a})$, however, requires that the private action remain subordinate.

But $\$ 5$ (a) does not permit government judgments to be given conclusive effect; under the analysis presented in Part I of this Note, they are limited to a prima facie presumption. To give conclusive effect to private judgments but only prima facie effect to government judgments would subordinate the government judgment to the private, thus reversing the hierarchy of government and private suits intended by $\$ 5(a)$. Courts may not invoke the doctrine of offensive collateral estoppel to bring about such a reversal without the express approval of Congress.

Review Under the Expediting Act, 48 ST. JoHN's L. REv. 241 (1973) (discussing government attempt to rely for discovery in enforcement suit against IBM on discovery in private suit against IBM by Control Data Corporation). Whatever the policy considerations, however, the language of $\$ 5$ (a) precludes giving conclusive effect to a private judgment even in subsequent government enforcement suits. See pp. $554-55$ \& n.52 supra. 